JURNAL IKA VOL 8 No. 2 DESEMBER 2020 JURNAL IKA : IKATAN ALUMNI PGSD UNARS

Vol. 8 No. 2, Desember 2020

E-ISSN: 2656-4459

https://unars.ac.id/ojs/index.php/pgsdunars/index

P-ISSN: 2338-3860

\title{
IMPLEMENTASI PEMBELAJARAN TATAP MUKA DI MASA PANDEMI COVID-19
}

\author{
Siti Faizatun Nissa ${ }^{1}$, Akhmad Haryanto ${ }^{2}$ \\ ${ }^{1,2}$ Institut Agama Islam Negeri Salatiga \\ Coreesponding Email : sitifaizatunnissa@gmail.com
}

Received : November 11, 2020 Revised : November 15, 2020 Accepted : November 18, 2020

\begin{abstract}
ABSTRAK
Penelitian ini bertujuan untuk mengetahui implementasi pembelajaran tatap muka di masa pandemi covid-19. Penelitian ini merupakan penelitian kualitatif dengan subjek penelitian guru SD N Suniarsih Kabuapaten Tegal. Teknik pengumpulan data yang digunakan adalah observasi dan wawancara. Hasil penelitian ini adalah bahwa pembelajaran tatap muka dimusim Covid-19 dapat dilaksanakan dengan: perencanaan pembelajaran RPP yang disesuaikan dengan kondisi pandemi; pelaksanaan pembelajaran dengan menitikberatkan pada penyampaian materi; penilian/ evaluasi yang dilaksanakan sesuai dengan kondisi yang ada; dan menataati protokol kesehatan. Kegiatan pembelajaran tatap muka tetap berlangsung normal meski ketersediaan waktu yang terbatas sesuai dengan aturan dari pemerintah. Dalam tahap penilaian guru tetap melakukan evaluasi untuk menilaian sikap (afektif) evaluasi materi seperti melaksanakan ulangan harian, Penilaian Tengah Semester (PTS), dan Penilaian Akhir Semester (PAS) untuk menilai aspek kognitif peserta didik.
\end{abstract}

Kata Kunci: Pembelajaran tatap muka, pandemi covid 19, RPP Covid-19

\begin{abstract}
This study aims to determine the implementation of face-to-face learning during the Covid19 pandemic. This research is a qualitative research with the research subject of teachers of SDN Suniarsih, Tegal Regency. The data collection techniques used were observation and interviews. The results of this study are that face-to-face learning in the Covid-19 season can be implemented by: planning lesson plans adapted to pandemic conditions; implementation of learning with an emphasis on the delivery of material; assessment / evaluation carried out in accordance with existing conditions; and maintaining health protocols. Face-to-face learning activities continue normally despite limited time availability according to government regulations. In the assessment stage, the teacher continues to carry out evaluations to assess the attitude (affective) of material evaluation such as carrying out daily tests, Middle Semester Assessment, and Final Semester Assessment to assess the cognitive aspects of students.
\end{abstract}

Keywords: Face-to-face learning, Covid 19 pandemic, RPP Covid-19 


\section{PENDAHULUAN}

Wabah Coronavirus 2019 (Covid-19) sangat mengguncang masyarakat dunia. Menurut World Health Organitazation (WHO), hingga saat ini terkonfirmasi 200 Negara di Dunia terjangkit wabah Covid-19 termasuk Indonesia. Hampir seluruh sektor kehidupan terkena dampak dari wabah Covid-19, tidak terkecuali di sektor pendidikan (P. Ayu Suci \& Gunawan, 2020)(Siahaan, 2020)(Syah, 2020). Dalam siaran pers (137/sipres/A6/VI/2020), pemerintah

melalui Kementerian Pendidikan dan Kebudayaan (Kemdikbud) telah menerapkan kebijakan learning from home atau belajar dari rumah (BDR) untuk satuan pendidikan yang berada di wilayah zona kuning, oranye, dan merah. Sedangkan bagi satuan pendidikan yang berada di zona hijau, dapat melaksanakan pembelajaran tatap muka dengan tetap memperhatikan protokol Kesehatan. Salah satu wilayah yang melaksanakan pembelajaran tatap muka adalah kabupaten tegal.

Covid-19 adalah penyakit jenis baru yang belum pernah diidentifikasi sebelumnya pada manusia (Fauci et al., 2020). Penyakit ini pertama kali ditemukan pada Desember 2019 di Wuhan, Ibukota Provinsi Hubei China, dan sejak saat itu menyebar secara global. Organisasi Kesehatan Dunia (WHO) mendeklarasikan wabah coronavirus 2019 sebagai Kesehatan Masyarakat Darurat Internasional (PHEIC) pada 30 Januari 2020. Tanda dan gelaja umum infeksi COVID-19 antara lain gejala gangguan pernapasan akut, seperti demam, batuk, dan sesak napas (Handayani et al., 2019). Masa inkubasi rata-rata 5-6 hari dengan masa inkubasi terpanjang 14 hari (Lauer et al., 2020). Sampai pada tanggal 4 Desember 2020 melalui website www.covid-19.go.id, Indonesia melaporkan jumlah kasus pasien positif corona bertambah 5.083 sehingga total keseluruhan mencapai 563.680 jiwa. Berbagai upaya pencegahan penyebaran virus Covid-19 pun dilakukan oleh pemerintah Indonesia, khususnya pada sektor Pendidikan pemerintah memberlakukan belajar dari rumah (BDR).

Sejak keluarnya Surat Edaran Kementerian Pendidikan dan Kebudayaan Nomor 4 tahun 2020 tertanggal 24 Maret 2020, maka selama masa darurat penyebaran covid-19 pelaksanaan pembelajaran di semua jenjang pendidikan dilaksanakan dari rumah, atau secara dalam jaringan (online). Tidak hanya pembelajaran, akan tetapi aktivitas pedidikan lainnya seperti evaluasi, administrasi, bahkan sampai penerimaan siswa baru pun dilakukan dengan cara online. Kebijakan ini sebagai langkah dalam memutus mata rantai penyebaran covid-19 dan menyelamatkan generasi muda dari wabah covid-19. 
Pendidik harus memastikan kegiatan belajar mengajar tetap berjalan walaupun dalam keadaan penyebaran Covid-19 (Asmuni, 2020). Kegiatan belajar mengajar tetap berjalan agar generasi emas tidak ketinggalan dalam belajar dan tetap melakukan pembelajaran demi kemajuan generasi penerus sebagai ujung tombak kemajuan bangsa di masa yang akan datang (Pujiasih, 2020). Oleh karena itu, diperlukan upaya dari seluruh pihak peduli terhadap pendidikan agar mengahasilkan generasi bangsa yang memiliki perilaku positif juga handal dalam bersaing dan berkompetensi baik secara lokal, regional, nasional, bahkan global meskipun dalam kondisi wabah covid-19 (Tenten, 2012).

Kegiatan belajar mengajar sesuai dengan surat edaran Kemdikbud Nomor 4 tahun 2020 dilakukan secara daring (online). Pembelajaran secara daring atau online learning merupakan model pembelajaran yang memanfaatkan teknologi berbasis computer, yang memungkinkan peserta didik dan guru bertemu melalui koneksi internet (Kuntarto, 2017). Pemanfaatan teknologi komputer dan internet ini, digunakan sebagai alat penyampaian materi/ media pembelajaran (Billah \& Yazid, 2020). Pada tataran pelaksanaanya pembelajaran daring memerlukan dukungan perangkat-perangkat mobile seperti smartphone atau telepon adroid, laptop, komputer, tablet, dan iphone yang dapat dipergunakan untuk mengakses informasi kapan saja dan dimana saja (Gikas \& Grant, 2013)(Haryanto \& Billah, 2020). Hadirnya teknologi sebagai media pembelajaran sangat membantu siswa dan guru dalam proses pembelajaran (Mahfudz \& Billah, 2020)(Haryanto \& Billah, 2020). Bahkan, media pembelajaran berbasis teknologi android dapat memfasilitasi siswa untuk dapat belajar secara mandiri, berulang, dan tidak terbatas ruang dan waktu (Sajidan et al., 2020)(Putri \& Billah, 2019).

Disusul dengan Siaran Pers Nomor 137/sipres/A6/VI/2020 mengenai penyelenggaraan pembelajaran pada tahun ajaran dan tahun akademik baru di masa pandemi corona virus (COVID-19) yang salah satu point pentingnya yaitu penyelenggaraan pembelajaran tatap muka boleh dilakukan pada zona hijau dengan tetap memperhatikan protokol kesehatan. Hal ini menjadikan beberapa wilayah Indonesia yang dalam kategori zona hijau melakukan kegiatan pembelajaran secara tatap muka. Salah satu wilayah yang melakukan kegiatan pembelajaran secara tatap muka yaitu kabupaten Tegal.

Pemerintah Kabupaten Tegal melalui Dinas Pendidikan dan Kebudayaan membuat Surat Edaran (SE) Nomor 420/04/60728 tertanggal 29 Juli 2020 tentang pelaksanaan pembelajaran tatap muka satuan pendidikan di lingkungan dinas pendidikan dan kebudayaan kabupaten tegal, 
memutuskan bahwa proses kegiatan belajar mengajar (KBM) pada satuan pendidikan tingkat PAUD, SD dan SMP mulai menggunakan metode pembelajaran tatap muka (PTM). Pembelajaran tatap muka merupakan pembelajaran klasikal dimana guru dan siswa bertemu secara langsung face-to-face dalam suatu ruangan atau forum ditempat yang sama. SD N Suniarsih di Kabupaten Tegal melakukan kegiatan belajar mengajar secara tatap muka. Dalam pelaksanaanya, guru SD N Suniarsih menghadapi beberapa masalah yang dialamai diantaranya: keterbatasan waktu pembelajaran, dan teknis pelaksanaan pembelajaran yang masih rancu. Kegiatan pembelajaran tatap muka dimusim pandemi Covid-19 ini, memang berbeda dengan tatap muka seperti biasanya sesuai dengan aturan dan arahan dari pemerintah.

Salah satu solusi alternatif yang dapat dilakukan yaitu dengan perumusan Rencana Pelaksanaan Pembelajaran (RPP) yang dibuat sesuai dengan kondisi sekolah serta situasi pandemi Covid-19 (Anggraeni \& Akbar, 2018)(Telupun, 2020)(Jalal, 2020). Dengan demikian, guru dapat mengatasi masalah keterbatasan waktu serta teknis dalam pelaksanaan pembelajaran. Untuk itu, perlu adanya penelitian mengenai implimentasi pembelajaran tatap muka dimusim Covid-19. Tujuan penelitian ini adalah untuk mengetahui bagaimana implementasi penerapan pembelajaran tatap muka di masa pandemi Covid-19 pada sekolah dasar.

\section{METODE PENELITIAN}

Penelitian ini merupakan penelitian kualitatif dengan metode pengambilan data observasi dan metode wawancara. Hasil penelitian kualitatif dapat berupa data deskriptif melalui kata-kata tertulis atau lisan dari orang-orang dan perilaku yang diamati (Billah, 2016). Observasi adalah alat pengumpulan data yang dilakukan dengan cara mengamati dan mencatat secara sistematik gejala-gejala yang diselidiki (Narbuko \& Achmadi, 2008). Observasi digunakan untuk mengamati secara langsung kegiatan pembelajaran tatap muka di masa pandemic Covid-19.

Sedangkan metode wawancara adalah cara pengumpulan data yang dilakukan dengan cara dialog, baik secara langsung (tatap muka) ataupun melalui saluran media tertentu antara pewawancara dengan yang di wawancarai sebagai sumber data (Sanjaya, 2013). Melalui metode wawancara ini, peneliti akan menggali informasi kegiatan pembelajaran yang dilakukan secara tatap muka di masa pandemi Covid-19. Untuk mendukung data penelitian maka dilakukan

observasi langsung dalam kegiatan pembelajaran dan wawancara yang mendalam kepada seluruh guru di SD N Suniarsih. Data yang diperoleh dari observasi dan wawancara tersebut 
selanjutnya dinarasikan untuk memperoleh gambaran umum implementasi pembelajaran tatap muka di masa pandemi covid-19.

\section{HASIL DAN PEMBAHASAN}

Penyebaran virus corona yang begitu cepat dan meluas menyebabkan beberapa sekolah yang ada di Indonesia harus melakukan pembelajaran jarak jauh atau online. Banyak aktivitas yang melibatkan kumpulan orang-orang kini mulai dibatasi karena adanya penyebaran visrus ini seperti: bersekolah, bekerja, beribadah dan lain sebagainya. Pemerintah sudah mengimbau untuk bekerja, belajar, dan beribadah dari rumah untuk menekan angka pasien yang terpapar covid-19.

Namun, berbeda dari sekolah lain beberapa sekolah yang berada di kabupaten tegal sudah terlebih dahulu memulai pembelajaran dengan metode tatap muka. Sesuai surat edaran Dinas Pendidikan kabupaten Tegal No. 420/04/60728 tentang penyelenggaraan KBM tatap muka tahun pelajaran 2020/2021. Sekolah yang berada di bawah naungan Dinas Pendidikan dan Kebudayaan Kabupaten Tegal, diperbolehkan melakukan pembelajaran tatap muka dengan ketentuan: (1) Masuk untuk semua kelas (I s.d VI); (2) 1 jam pelajaran 25 menit; (3) Istirahat 1 (satu) kali selama 15 menit, siswa tetap di dalam kelas; (4) 1 (satu) ruang maksimal 16 siswa; (5) Apabila siswa lebih dari 16, maka dibuat shift di hari berikutnya; dan (6) Jarak tempat duduk antar siswa minimal 1 meter.

Ketentuan-ketentuan tersebut juga didasarkan pada ketentuan: (1) Penyelenggaraan pembelajaraan KBM Tatap muka harus memperhatikan protocol Kesehatan; (2) Satuan pendidikan supaya menjalin komunikasi dengan stakeholder terkait (komite sekolah, pemerintah desa/kecamatan, puskesmas dll); (3) Melibatkan komite sekolah sebagai satgas di satuan pendidikan; dan (4) apabila terjadi pelanggaran terhadap protokol kesehatan, juknis, SOP atau ada indikasi warga yang terpapar Covid-19, maka proses KBM akan dihentikan. Berdasarkan keputusan di atas maka SD N Suniarsih Kabupaten Tegal melakukan kegiatan pembelajaran tatap muka untuk proses pembelajaran setiap harinya.

Dalam kegiatan pembelajaran, perencanaan menjadi awal proses sebelum pelaksanaan dan penilaian. Tujuan pembelajaran dapat tercapai dengan efektif dan efisien jika direncanakan dengan baik (Novalita, 2014). Perencanaan yang dibuat dituangkan ke dalam Rencana Pelaksanaan Pembelajaran (RPP). Rencana Pelaksanaan Pembelajaran (RPP) mengacu pada 
silabus dan kurikulum yang berlaku, kemudian dikembangkan sesuai dengan kondisi di satuan pendidikan. RPP dimodifikasi sesuai dengan kebutuhan dan keperluan.

Rencana Pelaksanaan Pembelajaran (RPP) pada satuan tingkat pendidikan Sekolah Dasar disusun berdasarkan tema/subtema dan KD yang dilaksanakan dalam satu atau lebih pertemuan. Guru akan merencanakan jumlah pertemuan dengan melihat muatan materi dan kegiatan yang dilakukan dalam pembelajaran. Kondisi pandemi Covid-19 ini, mengharuskan guru untuk membuat rencana pelaksanaan pembelajaran yang berbeda karena faktor keterbatasan waktu.

Berdasarkan hasil wawancara dengan guru kelas V di SD N Suniarsih, menyatakan bahwa kegiatan pembelajaran tatap muka saat pandemi Covid-19 berbeda dengan kondisi pada saat normal. Hal tersebut dibuktikan dengan durasi pembelajaran yang dipersingkat serta kegiatan pembelajaran hanya boleh dilakukan didalam kelas sesuai dengan aturan dari pemerintah setempat. Untuk itu guru dibimbing untuk menyusun RPP yang disesuaikan dengan kondisi saat ini. Selain itu hasil wawancara dengan kepala sekolah juga menjelaskan melalui Kelompok Kerja Guru (KKG) seluruh pendidik di SD N Suniarsih diberi pelatihan dalam penyusunan RPP yang baik, sesuai dengan ketentuan, dan cocok digunakan pada kondisi pandemi Covid-19. Hasil dari pelatihan tersebut, seluruh guru SD N Suniarsih dapat membuat RPP secara mandiri yang telah disederhanakan mulai dari materi serta kegiatan dalam kegiatan pembelajaran.

Rencana Pelakasanaan Pembelajaran (RPP) yang telah dibuat guru secara mandiri, kemudian dijadikan pedoman dalam melaksanakan kegiatan pembelajaran di kelas sesuai dengan kondisi saat ini. Setelah tahap perencanaan kemudian masuk kedalam tahap pelaksanaan, dalam pelaksanaan pembelajaran guru membagi kelas menjadi 2 shift, yaitu kelas pagi dan kelas siang. Hal ini disesuaikan dengan surat edaran oleh dinas Pendidikan Kabupaten Tegal. Proses pembelajaran berlangsung normal, dan sesuai dengan alur RPP yang telah dibuat oleh guru.

Tahap yang terakhir dalam pembelajaran yaitu tahap penilaian. Tahap penilaian proses belajar adalah upaya pemberian nilai terhadap kegiatan pembelajaran yang dilakukan oleh guru kepada peserta didik (Syaifuddin, 2017). Berdasarkan hasil pengamatan yang peneliti lakukan, setiap guru juga melakukan evaluasi, yaitu melakukan penilaian sikap dan penilaian materi seperti melaksanakan ulangan harian, Penilaian Tengah Semester (PTS) dan Penilaian Akhir Semester (PAS) seperti halayak umumnya. Dengan demikian setiap proses dalam pembelajaran 
tidak ada yang tertinggal, dari mulai perencanaan, pelaksanaan serta tahap evaluasi atau penilaian meskipun pada kondisi pandemi Covid-19.

\section{KESIMPULAN}

Berdasarkan hasil penelitian dan pembahasan di atas maka dapat disimpulkan bahwa pembelajaran tatap muka di kondisi pandemi Covid-19 dapat dilakukan dengan perencanaan yang matang. Dimulai dari penyusunan RPP yang dibuat seusai dengan kondisi pandemi covid19, pelaknaan pembelajaran yang diatur sesuai dengan rencana yang telah dibuat begitu pula dengan evaluasi atau penilian. RPP dibuat guru secara mandiri, dengan pelatihan serta diskusi dalam Kelompok Kerja Guru sehingga tersusunlah RPP yang cocok digunakan pada saat pandemi covid-19. Pelaksanaan pembelajaran dilakukan dengan membagi shif kelas agar tidak menyalahi aturan pemerintah dan proses pembelajaran tetap berlangsung.

\section{DAFTAR PUSTAKA}

Anggraeni, P., \& Akbar, A. (2018). Kesesuaian Rencana Pelaksanaan Pembelajaran Dan Proses Pembelajaran. Jurnal Pesona Dasar, 6(2), 55-65. https://doi.org/10.24815/pear.v6i2.12197

Asmuni. (2020). Probelmatika Pembelajaran Daring di Masa Pandemi Covid-19 dan Solusi Pemecahannya. Jurnal Paedagogy: Jurnal Penelitian Dan Pengembangan Pendidikan, 7(4), 281-288.

Billah, A. (2016). Pendidikan Karakter untuk Anak Usia Dini dalam Perspektif Islam dan Implementasinya dalam Materi Sains. ATTARBIYAH: Journal of Islamic Culture and Education, 1(2), 243-272.

Billah, A., \& Yazid, M. A. (2020). Developing an Android-Based Learning Media on Human Auditory System for Junior High School Students. Journal of Physics: Conference Series, 1567(042003), 1-6. https://doi.org/10.1088/1742-6596/1567/4/042003

Fauci, A. S., Lane, H. C., \& Redfield, R. R. (2020). Covid-19 - Navigating the Uncharted. New England Journal of Medicine, 382(13), 1268-1269. https://doi.org/10.1056/nejme2002387

Gikas, J., \& Grant, M. M. (2013). Mobile computing devices in higher education: Student perspectives on learning with cellphones, smartphones \& social media. Internet and Higher Education, 19, 18-26. https://doi.org/10.1016/j.iheduc.2013.06.002

Handayani, D., Hadi, D. R., Fathiyah, I., Erlina, B., \& Heidy, A. (2019). Corona Virus Disease 2019. Jurnal Respirologi Indonesia, 40(2), 128.

Haryanto, A., \& Billah, A. (2020). Establishing an Android-Based Integrated Sciences Glossary for Junior High School Students. Journal of Physics: Conference Series, 1567(042014), 1-6. https://doi.org/10.1088/1742-6596/1567/4/042014

Jalal, M. (2020). Kesiapan Guru Menghadapi Pembelajaran Jarak Jauh Di Masa Covid-19. SMART KIDS: Jurnal Pendidikan Islam Anak Usia Dini, 2(1), 35-40.

Kuntarto, E. (2017). Keefektifan Model Pembelajaran Daring dalam Perkuliahan Bahasa Indonesia di Perguruan tinggi. Journal Indonesian Language Education and Literature, 3(1), 53-65.

Lauer, S. A., Grantz, K. H., Bi, Q., Jones, F. K., Zheng, Q., Meredith, H. R., Azman, A. S., Reich, N. G., \& Lessler, J. (2020). The incubation period of coronavirus disease 2019 (CoVID-19) 
from publicly reported confirmed cases: Estimation and application. Annals of Internal Medicine. https://doi.org/10.7326/M20-0504

Mahfudz, A. Z., \& Billah, A. (2020). The Development of Android-Based Learning Media on Vibrations and Waves Topic for Junior High School Students. Journal of Physics: Conference Series, 1567(042009), 1-6. https://doi.org/10.1088/1742-6596/1567/4/042009

Narbuko, C., \& Achmadi, A. (2008). Metodologi Penelitian. Bumi Aksara.

Novalita, R. (2014). Pengaruh Perencanaan Pembelajaran terhadap Pelakasanaan Pembelajaran (Suatu Penelitian terhadap Mahasiswa PPLK Program Studi Pendidikan Geografi FKIP Universitas Almuslim). Lentera, 14(2), 56-61.

P. Ayu Suci, L., \& Gunawan. (2020). The Impact of Covid-19 Pandemic on Learning Implementation of Primary and Secondary School Levels. Indonesian Journal of Elementary and Childhood Education, 1(2), 2017-2019.

Pujiasih, E. (2020). Membangun Generasi Emas Dengan Variasi Pembelajaran Online Di Masa Pandemi Covid-19 Building a Golden Generation By Applying Various Online Learning in the Pandemic of Covid-19. Ideguru : Jurnal Karya Ilmiah Guru, 5(1), 42-48.

Putri, W. N., \& Billah, A. (2019). Pengembangan Media Pembelajaran Bahasa Arab berwawasan Sains berbasis Mobile Android. LISANIA: Journal of Arabic Education and Literature, 3(2), 163-179. https://doi.org/10.18326/lisania.v3i2.163-179

Sajidan, Billah, A., Masykuri, M., \& Sarwanto. (2020). The Development of Android-Based Science Learning Media on Human Eyes Topic. Journal of Physics: Conference Series, 1567(042026), 1-6. https://doi.org/10.1088/1742-6596/1567/4/042026

Sanjaya, W. (2013). Penelitian Pendidikan: Jenis, Metode dan Prosedur. Kencana.

Siahaan, M. (2020). Dampak Pandemi Covid-19 Terhadap Dunia Pendidikan. Jurnal Kajian Ilmiah, 1(1), 73-80. https://doi.org/10.31599/jki.v1i1.265

Syah, R. H. (2020). Dampak Covid-19 pada Pendidikan di Indonesia: Sekolah, Keterampilan, dan Proses Pembelajaran. SALAM: Jurnal Sosial Dan Budaya Syar-I, 7(5). https://doi.org/10.15408/sjsbs.v7i5.15314

Syaifuddin, M. (2017). Implementasi Pembelajaran Tematik di Kelas 2 SD Negeri Demangan Yogyakarta. Tadris: Jurnal Keguruan Dan Ilmu Tarbiyah, 2(2), 139. https://doi.org/10.24042/tadris.v2i2.2142

Telupun, D. (2020). Efektivitas Penerapan Model Pembelajaran Edutainment Untuk Memotivasi Peserta Didik Selama Pembelajaran Secara Daring Di Masa Pandemi Covid-19. Journal of Chemical Information and Modeling, 1(6), 254-262.

Tenten, H. (2012). Peranan Pendidikan Keluarga Dalam Mencegah Perilaku Negatif Remaja Melalui Pembinaan Karakter. STIKIP Siliwangi Bandung. 